\title{
NOTE
}

\section{Seasonal variation of the diel carbon budget of a marine macrophyte ecosystem}

\author{
M. Frankignoulle \& J. M. Bouquegneau
}

Laboratory of Oceanology, University of Liège, B-4000 Liège (Sart-Tilman, B6), Belgium

\begin{abstract}
Seasonal variation of the diel carbon budget of a Posidonia oceanica seagrass ecosystem was estimated in the Bay of Calvi (Corsica): the ecosystem served as a carbon sink from December to July and as a source from August to November. Comparison of these results with net primary production of the vegetation suggests that organisms associated with the seagrasses consume a quantity of oxygen, expressed as inorganic carbon, equal to about $55 \%$ of net organic carbon production. The quantitative significance of the annual carbon sink constituted by $P$. oceanica seagrass beds when determined using only vegetative biomass and turnover is discussed.
\end{abstract}

Although plankton production in the ocean is apparently a small net carbon sink. Smith (1981) considers that the production of marine macrophytes (i.e. benthic submerged plants, both seagrasses and macroalgae) is likely to be at least $10^{9}$ tons of carbon per year (i.e. $20 \%$ of the present yearly fossil-fuel carbon input to the atmosphere).

Among marine macrophytes, the seagrass Posidonia oceanica (L.) Delile dominates many Mediterranean coastal systems, but a decline in the extent of the seagrass beds has been recorded in response to several types of human activity (Bourcier 1986). However, in the Bay of Calvi, Corsica, the P. oceanica seagrass bed has been observed for the last $10 \mathrm{yr}$ and no clear change in its biomass and geographical distribution has been recorded (Bay pers. comm.). Bay (1984) measured leaf number per shoot, leaf-area index and leaf standing crop and primary productivity over the $2 \mathrm{yr}$ period 1975 to 1976 . The total $P$. oceanica leaf-blade productivity in the Bay of Calvi was estimated to be about 2871 tons DW for 1975 (1100 tons of carbon) and 3832 tons DW for 1976 (1500 tons of carbon), i.e. about 130 tons of carbon per $\mathrm{km}^{2}$. This suggests that $P$. oceanica accounts for only $26 \%$ of the mean production of the entire marine macrophyte community in the Bay of Calvi, based on Smith (1981).
However, Bay (1984) did not take into account respiration of the animals living in the system, nor natural leaching of dissolved organic compounds and subsequent bacterial activity, whose contributions have been reported by Velimirov (1986). As a whole, the Posidonia oceanica seagrass system of the Bay of Calvi is responsible for nearly all the diel variation of both dissolved oxygen and total inorganic carbon in the water column (Wehren et al. 1981, Frankignoulle \& Distèche 1984 , 1987, Frankignoulle et al. 1984). During our experiments, we measured daily variations of both dissolved oxygen and total inorganic carbon at different seasons over the 4 yr period 1982 to 1985, using a plexiglass incubator covering about 30 vegetative shoots of the seagrass, at a depth of $8 \mathrm{~m}$. The methods used $(\mathrm{pH}$, alkalinity and dissolved oxygen measurements), and one preliminary result, have been previously described (Frankignoulle et al. 1984).

In this note, we present the seasonal variation of net daily production of the seagrass ecosystem (i.e. Posidonia oceanica, rhizomes, epiphytes, benthic fauna, bacteria, sediments, etc.), expressed in $\Sigma \mathrm{CO}_{2}$ and $\mathrm{O}_{2}$ respectively fixed and evolved per day and per $\mathrm{m}^{2}$. Some discrepancies occur between the results of the 2 techniques (Fig. 1), a problem already noted by other authors (e.g. Johnson et al. 1981), and this probably results from processes independent of the activity of the seagrass bed, such as oxidation-reduction reactions, and oxygen accumulation in the leaves. Akalinity can also vary in the incubator as a result of carbonate dissolution or precipitation, notably when high $\mathrm{pH}$ variations occur. However, this variation of alkalinity may be neglected since its daily budget is zero (Frankignoulle 1986).

It appears that the seagrass system is a carbon sink from December to the end of July (Fig. 1). The highest values are recorded from May to June and decrease in 


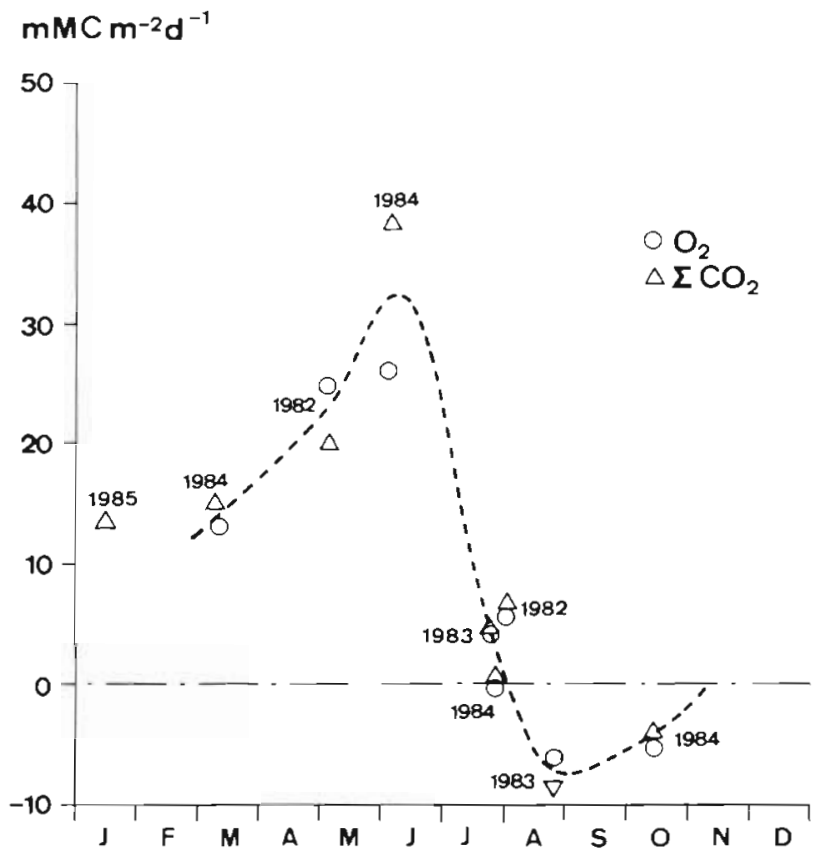

Fig. 1. Seasonal variation of the diel budget of carbon fixed (positive values) or evolved (negative values) by the Posidonia oceanica seagrass ecosystem of the Bay of Calvi, Corsica (estimated by both dissolved oxygen and inorganic carbon measurements). Values for May 1982 have been previously published by Frankignoulle et al. (1984).

July. In contrast, from August to November, the seagrass bed is a carbon source. These observations fit well with the general shape of the seasonal variation of the seagrass bed described by Bay (1984): June corresponds to the maximal total daily downward solar irradiance and is associated with a high photosynthetic yield. The process of decay of old leaves is maximal from July to November and the new generation of young leaves only begins to dominate the old in October. The fact that the seagrass system is a source of carbon from August to November results from the combined effects of decay of old leaves, maximal bacterial activity in this period, and high temperatures.

When considering the annual carbon budget of the Bay of Calvi, it is worth noting that both the seagrass bed ecosystem (this work) and the atmosphere (Frankignoulle 1986 and unpubl.) serve as a sink. From integration of the curve presented in Fig. 1, and taking into account the total surface of seagrass in the bay 1071 ha) and the decrease of activity as a function of depth described by Bay (1984), we can estimate the global sink of carbon resulting from the seagrass ecosystem activity to be about 600 tons $\mathrm{yr}^{-1}$, i.e. $45 \%$ of the net production of the seagrasses (1300 tons carbon $\mathrm{yr}^{-1}$; Bay 1984). In our case, the whole seagrass system was considered and organisms associated with the seagrasses probably consume a quantity of $\mathrm{O}_{2}$, expressed in $\Sigma \mathrm{CO}_{2}$, equal to $55 \%$ of the net organic production The burying of 1000 tons of carbon by Posidona oceanica implies therefore a production of 550 tons of inorganic carbon by the organisms present in the ecosystem, so that, on a global scale, we consider that the significance of the annual sink of carbon constituted by a marine macrophyte ecosystem, such as a $P$. oceanica seagrass bed, is over-estimated when it is determined using only vegetative biomass and turnover.

In this note, our intention is to point out that the burying of carbon by Posidonia oceanica is accompanied by a significant production of inorganic carbon by the organisms associated with the seagrasses. To our mind, this should be taken into account when considering the contribution of marine macrophyte ecosystems in the biogeochemistry of carbon. Further research is needed to estimate the significance of such a phenomenon when considering other marine macrophyte ecosystems (Zostera, Thalassia, Halodule, etc.).

Acknowledgements. J. M. Spronck, J. C. Bardoux and C. Marchand are acknowledged for their technical assistance. Electrode glassware was kindly provided by Dr A. E. Bottom (Kent Industrial Instruments Ltd, England). This work was supported by FNRS (with which J. M. Bouquegneau is a 'Chercheur Qualifié'), by the Ministry of Science Policy (Belgium) and by C.E.E. contract No. ENV-770-B

\section{LITERATURE CITED}

Bay. D. (1984). A field study of the growth dynamics and productivity of Posidonia oceanica (L.) Delile in Calvi Bay, Corsica. Aquat. Bot. 20: 43-64

Bourcier, D. (1986). Evolution, en cinq années, des herbiers à Posidonia oceanica et du macrobenthos circalittoral. Action conjuguée des activités humaines et des modifications climatiques. Vie Milieu 36 (1): 1-8

Frankignoulle, M. (1986). Le système $\mathrm{CO}_{2}$ en milieu marin: activité biologique, interactions air-mer, caractérisation des masses d'eau dans la couche de surface. Doctorat thesis, Univ. of Liège, Belgium

Frankignoulle, M., Bouquegneau, J. M., Ernst, E., Biondo, R., Rigo, M., Bay, D. (1984). Contribution de l'herbier de Posidonies au métabolisme global de la baie de Calvi. Premiers résultats. In: Boudouresque, C. F., Jeudy de Grissac, A., Olivier, J. (ed.) International workshop on Posidonia oceanica beds, Vol. 1. GIS Posidonie publ., Marseille, p. 277-282

Frankignoulle, M., Distèche, A. (1984). $\mathrm{CO}_{2}$ chemistry in the water column above a Posidonia seagrass bed and related air-sea exchanges. Oceanologica Acta 7: 209-219

Frankignoulle, M., Distèche, A. (1987). Study of the transmission of the diurnal $\mathrm{CO}_{2}$ concentration change observed above a Posidonia seagrass bed. A method to determine the turbulent diftusion coefficient in a 8 meter water column. Cont. Shelf Res. 7: 67-76

Johnson, K. S., Burney, C. M., Sieburth, J. McN. (1981). Enigmatic marine ecosystem metabolism measured by 
direct $\mathrm{CO}_{2}$ and $\mathrm{O}_{2}$ flux in conjunction with $\mathrm{DOC}$ release and uptake. Mar. Biol. 65: 49-60

Smith. S. V. (1981). Marine macrophytes as a global carbon sink. Science 211: 838-840

Velimirov, B. (1986). DOC dynamics in a Mediterranean seagrass system. Mar. Ecol. Prog. Ser. 28: 21-41
Wehren, J. C., Bouquegneau, J. M., Gillain, G., Distèche, A. (1981). Mesure en continu de l'évolution nycthémérale du $\mathrm{pH}$ de l'eau de mer au niveau des herbiers de Posidonies (Posidonia oceanica [L.] Delile) dans la baie de Calvi. Bull. Soc. R. Sci. Liège 11-12: 549-551

This note was submitted to the editor; it was accepted for printing on March 31, 1987 